\title{
A Comparative Research on Levels of Students' Formation Skills of Their Career Advancement Portfolio in Secondary and Higher Education Systems
}

\author{
Albina Rafisovna Shaidullina ${ }^{1}$, Guzel Rafkatyevna Fassakhova ${ }^{2}$, Gyuzel Khusainovna Valeyeva ${ }^{3}$, Galiya \\ Bulatovna Khasanova ${ }^{4}$, Valentina Aleksandrovna Komelina ${ }^{5} \&$ Tatyana Leonidovna Ivanova ${ }^{6}$ \\ ${ }^{1}$ Almetyevsk State Oil Institute, Russia \\ ${ }^{2}$ Kazan State Agrarian University, Russia \\ ${ }^{3}$ Sibay institute (branch) of Bashkir State University, Russia \\ ${ }^{4}$ Kazan National Research Technological University, Russia \\ ${ }^{5}$ Mari State University, Russia \\ ${ }^{6}$ The Institute of Economics, Management and Law, Russia \\ Correspondence: Albina R. Shaidullina, Almetyevsk State Oil Institute, Lenin Street, 2, 423450, Almetyevsk, \\ Russia. E-mail: albina-plus@mail.ru
}

Received: September 30, 2014 Accepted: November 14, $2014 \quad$ Online Published: December 2, 2014

doi:10.5539/ass.v11n1p375 URL: http://dx.doi.org/10.5539/ass.v11n1p375

\begin{abstract}
Portfolio is an effective tool to develop graduating students' careers since it contains more detailed information for employers than the standard resume. The aim of this article is to conduct a comparative study of students' skills level in drawing and making up career development portfolio within systems of secondary and higher education. The purpose of career progress portfolio, its structure and content are well described in this article, progress and results of the survey in order to identify the development level of above-mentioned skills are represented in the article. Article materials may be useful both for teachers and for students when making up their portfolio.
\end{abstract}

Keywords: career development portfolio, graduating students, employers, secondary and higher schools, professional education system

\section{Introduction}

To facilitate relationship with future employer and to help graduating students stay ahead of potential competitors a professional advancement portfolio can stimulate initiator's activity and encourage him to generate appropriate behavior. However, during employers' interview there have been an observation that young professionals when making their self-presentations practically do not use portfolio as a form of report (Kimball, 2002; Veselova, 2010; Grigorenko, 2007; Khairullina, 2007; Masalimova, 2013).

Career advancement Portfolio (CAP) - is an already well-established career planning method, and it is widely accepted in Western countries. PAP is a package of documents in paper and / or electronic version, which reflects all student's achievements (both academic and personal) (Akbieva, 2008; Polezhaev \& Polezhaeva, 2008; Sakhieva, 2011; Lobashev, 2006). Portfolio is made up in such way as to ensure an effective communication between students and academic supervisors, teachers and tutors at high school during study period, as well as with potential employers after high school graduation.

CAP is meant to reflect all student's achievements: student should regularly update his CAP as he moves further on his study track according to his compulsory and extra studies during his professional training period, as well as to include information defining his abilities, skills and competencies (Mogilevkin, 2007).

CAP can be useful to keep track of such documents as:

- final thesis or course paper materials

- internship reports and recommendation letters; 
- scientific conference materials;

- abstracts from articles at professional journals;

- honors and certificates of attendance from seminars, forums and conferences;

- honor certificates at the Hall of Fame at university;

- certificates of successful professional development at training and educational programs (for instance, "career technology" program, training course for advanced PC user, etc.);

- scholarship certificates,

- recommendation letters from teachers and tutors (Tazutdinova, 2010; Tsaritsentseva, 2009; Kuptsova, 2010).

Student using CAP can positively impress future employer since this tool can help the applicant to jump ahead of his competitors, as this fact characterizes him as a representative of a new wave of employees living up to date with high technologies and modern trends.

\section{Methodological Framework}

\subsection{Portfolio Content}

Career advancement portfolio includes the following items:

- Resume made up in a professionally written, meeting modern requirements form;

- A list of attended courses on main activity areas within related educational fields, including additional specialization, training programs, specific workshops and master classes performed by leading educators;

- A list of extracurricular activities, and any positions where student implemented his leadership skills (e.g., coordinator of a student group, head of of students' research group, mentor for first year students, etc.);

- Career potential description and readiness for career development in terms of acquiring necessary skills and experience;

- Recommendation letters from leading teachers, course and thesis projects tutors, internship coordinators, etc. (Lizunova, 2008; Kolodkina, 2008).

\subsection{Portfolio Aims}

CAP is double-purposed - on the first hand, it is aimed to evaluate educational and scientific achievements, on the other hand, - to evaluate student's readiness for professional career.

1. The purpose of educational and scientific evaluation. In this case CAP serves as an assessment tool, changing over the time and assured through paper proofs as readiness for training development and professional growth while studying at university. Along with training courses attendance, portfolio displays student's achievements in skills and competencies enhancement required for a successful career. Over time, CAP turns into a complex structure of student's abilities and achievements.

CAP is an optimal way to sum up student's educational and scientific achievements after consultations with his supervisor and other teachers at university's department or faculty and to provide opportunities for his further possible science career (e.g., master's degree or post-graduate programs). Since two-leveled professional educational system (Bachelor's and Master's degrees) are widely accepted nowadays in Russia, properly made up CAP becomes one of the most important selection criteria when entering Master's degree.

2. The purpose of assessing readiness for a career. PEP is an important instrument for the transfer of business and personal information about the graduates of the university (in the form of a resume and letters of recommendation) to potential employers for employment under the terms of a partial (still in training), and full employment.

\section{Results and Discussions}

\subsection{Portfolio Content}

Portfolio is an effective tool for career development; it contains much more information for analysis than the standard resume. Professionally made up CAP allows employer to see at once potential candidate's training level and a whole range of his skills and abilities, and it also creates conditions for future employer to take correct job decisions. Professionally written CAP helps graduated students to draw employer's attention to his resume and underline his competitive advantages comparing to other candidates. Portfolio samples are represented in the table beneath: 
Table 1. Portfolio content

\begin{tabular}{|c|c|}
\hline $\begin{array}{c}\text { Official } \\
\text { documents }\end{array}$ & $\begin{array}{l}\text { - general Certificate of secondary education, } \\
\text { - internationally known local, foreign and city competitions certificate of participation } \\
\text { - certificate for participation in grants, music, sport or art school certificates } \\
\text { - internship, training courses, specific professional events attendance certificates } \\
\text { - articles in magazines, newspapers, photo or/and video materials as proof for } \\
\text { professional success } \\
\text { - achievements list on other personal success stories which cannot be documentary proven }\end{array}$ \\
\hline Life experience & $\begin{array}{l}\text { - autobiography } \\
\text { - "view into my past" essay } \\
\text { - the most important life events: their assessment and significance analysis, } \\
\text { - shaping personality stages, including people and events influencing this process } \\
\text { - newspaper, photo and video materials, testimonies } \\
\text { - recommendation letters from well-known (optional) people about you } \\
\text { - feedback from previous workplaces }\end{array}$ \\
\hline $\begin{array}{l}\text { University period, } \\
\text { under-professional } \\
\text { and professional } \\
\text { training }\end{array}$ & $\begin{array}{l}\text { - grades at all stages of professional training } \\
\text { - the most favorite subjects, teachers, motivators for study, main educational periods } \\
\text { - possible changes in profession/university/thesis topic preferences, } \\
\text { - teachers and education tutors feedbacks } \\
\text { - internship places and functions description }\end{array}$ \\
\hline Scientific work & $\begin{array}{l}\text { - Scientific works list } \\
\text { - Scientific letters } \\
\text { - Annotations for scientific works } \\
\text { - others'scientific works/monographs'/study materials review, } \\
\text { - scientific references }\end{array}$ \\
\hline $\begin{array}{l}\text { Elective courses, } \\
\text { creative works }\end{array}$ & $\begin{array}{l}\text { - extra courses list, grades, certificates, comments, acquired skills } \\
\text { - structured feedback/ references on scientific materials in mass media (optional) }\end{array}$ \\
\hline
\end{tabular}

\subsection{Experiment Stages and Its Results}

Along with educational process introduction in portfolio, we conducted a survey of students, teachers and employers in order to identify the most important aims of this portfolio and its contents (presented in Table 2).

Table 2. Comparative analysis of portfolio aims its contents

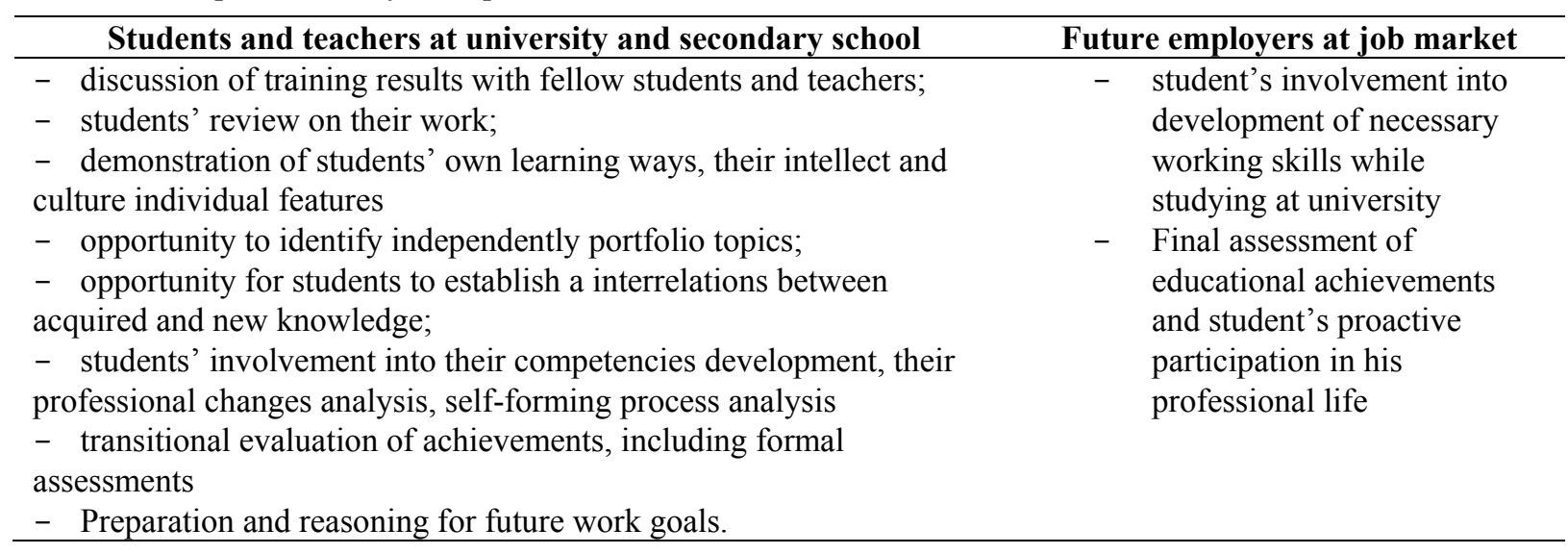

In order to make up and improve a portfolio content a scheme was elaborated on recurrence principle (Figure 1).

We started portfolio method introduction in 2010. Graduating students were making up their portfolio while summarizing their learning process. Third-year students were making up CAP for the period of 2010-2014. During final assessment in 2013 and 2014, along with final thesis they represented their portfolio. 
After this experiment students of Almetyevsk State Oil Institute (ASOI) had very strong skills of making up their portfolio: those continuing their education after Almetyevsk Polytechnical College (APC) - 46\%, average skills level - 35\% low skills level - 19\%.

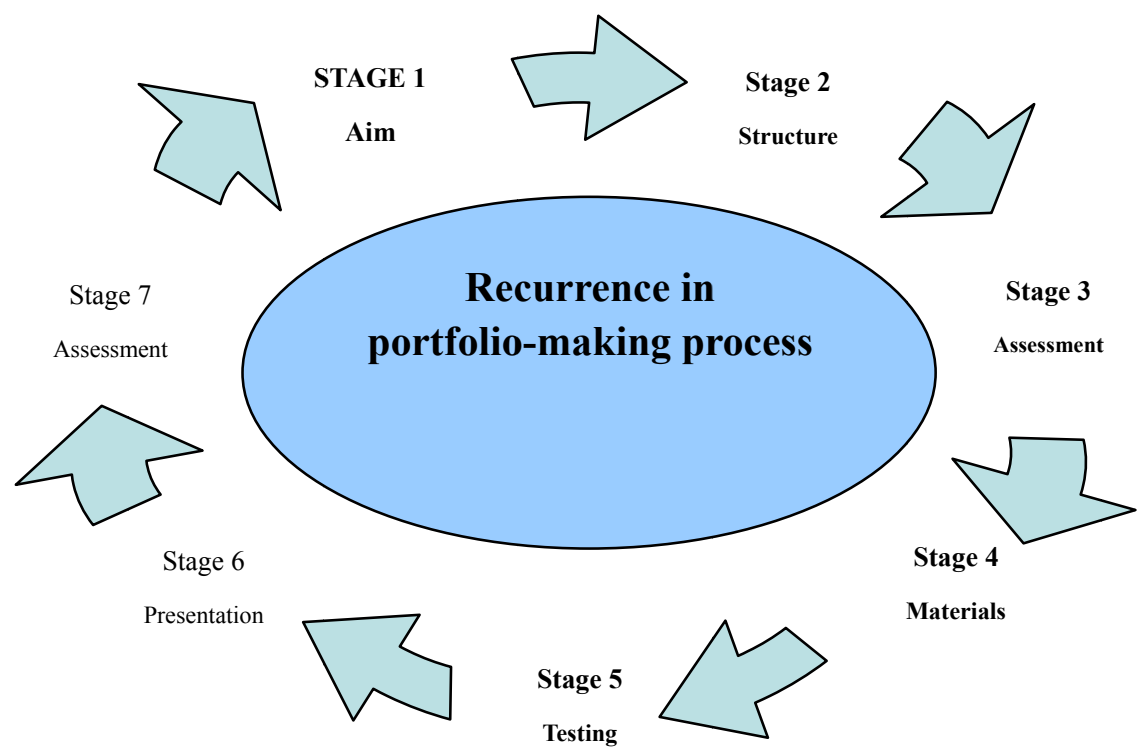

Figure1. Recurrence in portfolio

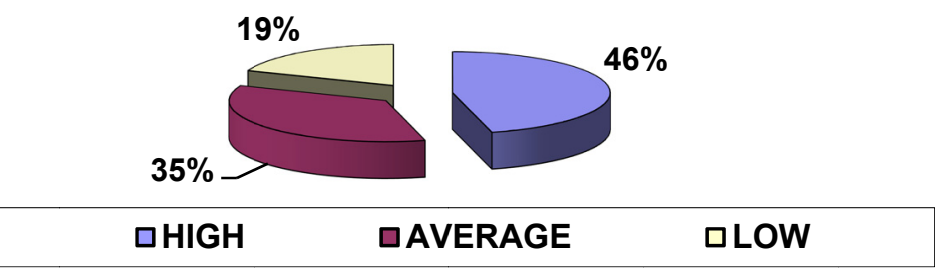

Figure 2. Levels of formation skills in making up portfolio among students of ASOI after graduating APC

Among ASOI students studying after secondary school a high level of making up portfolio showed $26 \%$ of students, average skills level- $38 \%$ low skills level - $36 \%$.

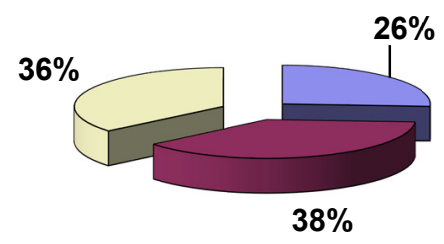

口HIGH $\quad$ 口AVERAGE $\quad$ QLOW

Figure 3. Levels of formation skills in making up portfolio among ASOI students after graduating secondary school

Analyzing the experiment's results, we can conclude that ASOI students after graduating APC had stronger skills of making up portfolio, which in turn has a positive impact on their demand level for such graduates. 


\section{Conclusion}

In systems of secondary and high education, there are traditionally implemented methods, forms and means of control, which in many cases coincide with each other. However, during employers' interview we have identified their wish for young professionals to represent themselves in the form of portfolio. Career advancement portfolio was elaborated in order to make it an effective tool for career development since it contains much more information for analysis than the standard resume. The scheme in form of cycle was designed to create and improve portfolio content. According to experiment's results students of institutions continuing their studies after universities and colleges have stronger skills of making up a portfolio, which in turn has a positive impact on demand level for graduates within the job market.

\section{References}

Akbieva, Z. S. (2008). Psychology of career and vocational relevant behavior specialist (p. 328). Moscow. Publisher Moscow Psychological and Social Institute.

Grigorenko, E. V. (2007). Portfolio in high school: Guidelines for the creation and use. Tomsk. Retrieved from http://ii.tsu.ru/userfiles/metodichkaportfoliovvuze.doc.

Khairullina, E. R. (2007). Orientation of students to self-development of core competencies in the design and creative activity. Science and Education Journal, 7.

Kimball, M. (2002). The Web Portfolio Guide: Creating Electronic Portfolios for the Web (p. 208). Texas. Tech University.

Kolodkina, L. S. (2008). Portfolio of students in teaching practices. School technology, 3, 129-133.

Kuptsova, L. I., Martynova N. V., \& Tomilina, O. P. (2010). Portfolio as a method of forming a professional competencies. Specialist, 3, 18.

Lizunova, L. R. (2008). Application technology portfolio in special (correctional) educational. Perm: 42.

Lobashev, V. D. (2006). Technology portfolio. Vocational Education, 8, 18-19.

Masalimova. A. R. (2013). Corporate training the mentors (p. 183). Printing Service - XXI Century Press.

Mogilevkin, E. A. (2007). Career development: diagnosis, technology, training (p. 336). Petersburg. Speech Press.

Piskunova, E. V. (2008). Professional Passport teacher. Humanities vector, 1, 21-27.

Polezhaev. V. D., \& Polezhaeva, M. V. (2008). Portfolio of the student as a tool for creating an individual learning path. Modern high technologies, 3, 77-78

Sakhieva, R. G. (2011). Vocational school student portfolio (p. 5). Kazan. Academy of Social Education.

Tazutdinova, E. H. (2010). Portfolio in the training of students for future educational activities: the dissertation of the candidate of pedagogical sciences (p. 200). Kazan.

Tsaritsentseva. O. P. (2009). Career orientation of today's youth: theory, experiment, training (p. 186). Orenburg.

Veselova. V. S. (2010). Values of modern society and education. Values and meanings, 2(5), 64-73.

\section{Copyrights}

Copyright for this article is retained by the author(s), with first publication rights granted to the journal. This is an open-access article distributed under the terms and conditions of the Creative Commons Attribution license (http://creativecommons.org/licenses/by/3.0/). 